\title{
The influence of training, teaching experience, principal leadership, the understanding of curriculum to teacher's performance
}

\author{
Afifah Asra' ${ }^{1}$, Syamsul Amar ${ }^{2}$, Azwar Ananda ${ }^{3}$ \\ ${ }^{123}$ Universitas Negeri Padang, Padang - Indonesia, (afifahasra@yahoo.com)
}

\begin{abstract}
The research aimed to get to identify: first the influence of training, teaching experience, principal leadership to the understanding of Social Science curriculum, second the influence of training, teaching experience, principal leadership, and the understanding of Social Science curriculum to teacher's performance. This is a causal descriptive research. There are 57 teachers as research sample. This research findings were: first, there was a significant influence of training, teaching experience, principal leadership to the understanding of Social Science curriculum at state senior high schools in Pariaman City. The better of teacher training, good teaching experience, and good principal leadership, will be the better of teacher's understanding of the curriculum. Second, there are was a significant influence of training, teaching experience, principal leadership, and understanding of curriculum toward teacher's performance. The better of training, teaching experience, principal leadership, and understanding of the curriculum will be the better the teacher's performance.
\end{abstract}

Keywords: training, teaching experience, principal leadership, understanding of curriculum, teacher's performance.

\section{Introduction}

In education, teacher has an important and strategic role because they directly interact with their students in teaching them constructive values. In an educational institution teacher is the first person who guides, teaches, and trains students to reach maturity. Teacher is a profession which requires skill, responsibility and professional loyalty, and that is why this job is theoritically impossible to be entrusted to an untrained and incompetent person.

Teacher's success in teaching and learning is decided by their performance as an educator. Teacher performance is teacher's skill in doing their task and responsibility as a teacher for the sake of achieving predetermined objectives or goals. So, teacher performance plays an important role in achieving educational purposes and optimal learning process.

Basically, there are several factors that could affect teacher performance. They are training, teaching experience, leadership of the principle, and understanding of curriculum. Government's effort in improving teacher's educational quality is explained in the Act (UU) Number 14 Year 2005 regarding teacher and lecturer. In the Act, it is mentioned that to improve teacher's potential, training 
and upgrading need to be held. Therefore, teacher training and upgrading are enough to affect teacher's performance quality.

Sufficient teaching experience, years that a teacher has gone through in teaching, will support the achievement of pre-determined goals. Teacher's longer teaching experience will result in their better knowledge and skill of planning, performing, managing, and evaluating the learning process and wisdom in dealing with problems in school. A sufficient teaching experience will positively affect teacher's performance in school. As explained by Danim (2011: 23), teacher who has longer teaching experience tends to know better what activities and teaching practices should be used for teaching certain materials.

As an influential person and a determinant of school progress, School's Principal must have administrative skill, high commitment, and be proficient in performing their duties. Therefore, the Principal should lead according to school situation and needs for the sake of improving teacher's good performance. Good principal leadership should be able to improve teacher's performance, for example, through training program for educational personnel's skill and ability.

Teacher's role in teaching and learning is inseparable from curriculum. Curriculum, especially in high school, is defined as a set of learning experiences designed for high school students in an effort to achieve educational goals. In this case, according to Sanjaya (2009:28), teacher plays a role as the one who implements the curriculum, adapts it with student's characteristics and needs and with needs of the region, develops and studies the curriculum. This means that teacher has an important involvement and role in both teaching-learning and designing and implementating the curriculum

Lack of training, teaching experience, and Principal's leadership skill will affect teacher's understanding of the curriculum. When curriculum implementation is not consistent, teacher's performance will be low with the result that the quality of national education will be low as well.

Based on those problems, the reseacher was motivated to study the extent to which teacher's performance was affected by teacher training, teaching experience, leadership of the principal, and teacher's understanding of curriculum. This research is titled The Effect of Teacher's Training, Teaching Experience, Leadership of the Principal, and Teachers' Understanding of Curriculum on Teacher's Performance. This research was conducted on Social Science teachers at state senior high schools in Pariaman City.

\section{Method}

Based on those problems, the researcher decided to conduct a descriptive causal research on the problems. Descriptive causal research clearly ilustrates the facts that happen and finds the effect of each independent variable $(X)$ on dependent varibale $(Y)$. Research data was obtained from respondents through questionnaire. Obtained data was presented descriptively and analyzed by testing the proposed hypothesis. The Data Analyzed with statistical package of social science (SPSS) Version of 18.

Population of this research was all Social Science teachers from 6 state senior high schools in Pariaman with the total of 66 teachers. Intrument used in this research was questionnaire which applied Likert Scale. The questionnaire was compiled using several indicators that represent each variable. Data analysis technique being used was inductive analysis. In path analysis, there is prequisite testing of the analysis including (1) Normality test which aims to determine whether the data is normally distributed, and (2) Homogeneity test which aims to find whether the data has homogeneity of variance. Path analysis was used in order to find the effect of exogenous variables on other endogenous variables (variable intervening) 


\section{Result and Discussion}

The data in this research was analysed through path analysis. Obtained data was processed by SPSS v.18.0 to find the effect of exogenous variables on endogenous variables. The analysis was divided into 2 phases as mentioned as follows:

Sub Structure 1: The effect of Variables of Teacher Training (X1), Teaching Experience (X2), and Leadership of the Principle (X3) on Understanding of Curriculum (X4)

In this phase, the researcher discusses about the effect of causal variables (independent) of teacher training (X1), teaching experience (X2), and leadership of the Principal (X3) on teacher's understanding of curriculum $(\mathrm{X} 4)$ where $\mathrm{X} 4$ serves as intervening variable. The result of data processing is presented in the following table.

Table 1.

Path Coefficients of Teacher Training $\left(X_{1}\right)$, Teaching Experience $\left(X_{2}\right)$, and Leadership of the Principle $\left(X_{3}\right)$ on Understanding of Curriculum $\left(X_{4}\right)$

\begin{tabular}{|c|c|c|c|}
\hline \multirow[t]{2}{*}{ Model } & Standardized Coefficients & \multirow[t]{2}{*}{$\mathrm{t}$} & \multirow[t]{2}{*}{ Sig. } \\
\hline & Beta & & \\
\hline $\mathrm{X} 1$ & ,269 & 2,576 & 013 \\
\hline $\mathrm{X} 2$ & ,238 & 2,523 & 015 \\
\hline $\mathrm{X} 3$ & ,461 & 4,320 &, 000 \\
\hline
\end{tabular}

Table one shows a partial testing done in order to know the effect of each causal variable on result variable (dependent). It also tests path direction. The analyses are :

a. The analysis of SPSS shows path coefficient of $\mathrm{P}_{\mathrm{x}_{4} \mathrm{X}_{1}}=0,269$, with the significance level of $0,013<\alpha$ $=0,05$. This also means that path coefficient of Teacher Training $\left(X_{1}\right)$ on Understanding of Curriculum $\left(X_{4}\right)$ is significant and there is a significant effect of Teacher Training $\left(X_{1}\right)$ on Understanding of Curriculum $\left(\mathrm{X}_{4}\right)$. The analysis also shows a positive effect of Teacher Training (X1) on Understanding of Curriculum (X4). In other words, the more teachers attend the training the more they understand the curriculum.

b. Result of analysis shows that path coffecient of $\mathrm{Px}_{4} \mathrm{X}_{2}=0,238$, with significance level of $0,015<\alpha=$ 0,05 . It indicates a significant coefficient and effect of Teacher's teaching experience $\left(X_{2}\right)$ on Understanding of Curriculum $\left(\mathrm{X}_{4}\right)$ The result also tells a positive effect of Teacher's Teaching Experience $\left(\mathrm{X}_{2}\right)$ on Understanding of Curriculum $\left(\mathrm{X}_{4}\right)$. So, the more experienced the teachers are in teaching, the better they understand the curriculum.

c. The analysis shows coefficient of path $P_{x 4 \times 3}=0,461$, with sig level of $0,000<\alpha=0,05$. This means that path coefficient of Leadership of the Principal $\left(x_{3}\right)$ on Understanding of Curriculum $\left(x_{4}\right)$ is significant. The effect is also significant and positive. This means, the better Principal's leadership is the better teacher's understanding of the curriculum is.

d. The effect of other variables

The effect of other variables is calculated by using following formula

$$
\begin{aligned}
\mathrm{PX}_{4} \varepsilon_{1} & =\sqrt{1-R^{2} \mathrm{YX}_{1 \times 2 \times 3}} \\
& =\sqrt{(1-0,641)} \\
& =\sqrt{0,359} \\
& =0,5992
\end{aligned}
$$

From the equation, it is known that the contribution of other variables which cannot be included in this research is $0,5992^{2}=0,359=35,90 \%$. 
Based on those path coefficient, path's equation can be written as follow:

$\mathrm{X} 4=\mathrm{Px}_{4} \mathrm{X}_{1} \mathrm{X}_{1}+\mathrm{P}_{4} \mathrm{X}_{2} \mathrm{X}_{2}+\mathrm{Px}_{4} \mathrm{X}_{3} \mathrm{X}_{3}+\mathrm{Px}_{4} \varepsilon 1$

$=0,269 X_{1}+0,238 X_{2}+0,461 X_{3}+0,599$

Sub Structure 2: The Effect of Teacher Training $\left(X_{1}\right)$, Teaching Experience $\left(X_{2}\right)$, Leadership of the Principle $\left(\mathrm{X}_{3}\right)$ and Understanding of Curriculum $\left(\mathrm{X}_{4}\right)$ on Teacher's Performance $(\mathrm{Y})$

Second test was done to analyze the effect of independent variables of Teacher Training $\left(X_{1}\right)$, Teaching Experience $\left(X_{2}\right)$, Leadership of the Principal $\left(X_{3}\right)$ and Understanding of the curriculum $\left(X_{4}\right)$ on dependent variable of Social Science Teacher's Performance $(Y)$ at state senior high schools in Pariaman City, both simultaneously and partially. The result SPSS analysis is presented in Table 2 below:

Table 2. t Test Coefficientsa

\begin{tabular}{rrrrr}
\hline \multirow{2}{*}{ Model } & \multicolumn{2}{c}{ Standardized Coefficients } & \multicolumn{2}{c}{ Sig. } \\
\cline { 2 - 3 } X1 & Beta & & \\
\hline X2 & 211 & 2,195 &, 033 \\
\hline X3 &, 176 & 2,037 &, 001 \\
\hline X4 &, 367 & 3,417 &, 026 \\
\hline
\end{tabular}

According to Table 2, $t$ test scores of exogenous variables on endogenous variable are interpreted as follow:

a. The effect of teacher's training variable $\left(\mathrm{X}_{1}\right)$ on teacher's performance variable $(\mathrm{Y})$

Table 2 shows the value of $\mathrm{Pyx}_{1}=0,211$ on significance level $0,033<0,05$. This indicates a significant effect of variable $X_{1}$ on variable $Y$ which means Teacher Training $\left(X_{1}\right)$ significantly affects Teacher's Performance $(Y)$. The better teacher's perception is about attending the training the better their teaching performance is.

b. The effect of teaching experience variable $\left(\mathrm{X}_{2}\right)$ on teacher's performance $(\mathrm{Y})$ variable

The result of data processing shows the value of $\mathrm{Pyx}_{2}=0,176$ on significance of signifikansi $0,047<$ 0,05. This means the effect of Teaching Experience $\mathrm{X}_{2}$ on Teacher's Performance $(\mathrm{Y})$ is significant. In other words, the longer teacher's teaching experience is the higher their performance is in teaching the subject, in this case Social Science.

c. The effect of leadership of the principle $\left(\mathrm{X}_{3}\right)$ variable on teacher's performance $(\mathrm{Y})$ variable The table shows the score of $\mathrm{Pyx}_{3}=0,367$ on significance of $0,001<0,05$. This numbers suggest a significant effect of variable $X_{3}$ (Leadership of the Principal) on variable $Y$ (Teacher's Performance). So, the better Principal's leadership is in the school the higher Social Science teacher's performance is in state senior high school in Pariaman.

d. The effect of understanding of curriculum $\left(\mathrm{X}_{4}\right)$ variable on teacher's performance $(\mathrm{Y})$ variable Data analysis in Table 2 shows the score of $\mathrm{Pyx}_{4}=0,272$ on the significance of $0,026<0,05$. This means that there is a significant effect of Understanding of Curriculum (variable $\mathrm{X}_{4}$ ) on Teacher's Performance (variable Y). In other words, the better teacher's understanding of the curriculum is the higher teacher's performance is in teaching the subject.

e. The effect of other variables

The effect of other variables is calculated by using this formula: 


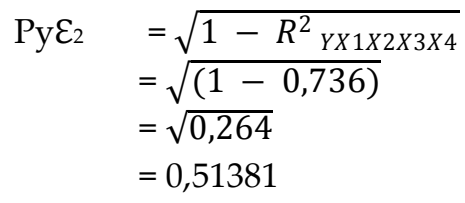

The equation tells the value of other variables' contribution, which cannot be included in this research, on Teacher's performance. The values is $0,5138^{2}=0,264=26,4 \%$.

Based on path coefficients mentioned above, the analysis can be concluded in the form of following path's equation:

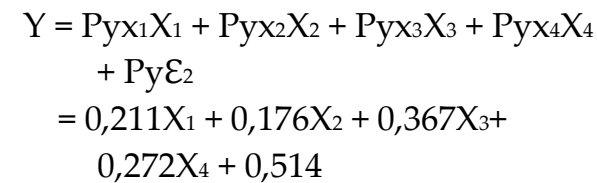

From the analysis about the effect of independent variable on dependent variable above, it is known that direct effect of teacher training on teacher's performance has a score of $4.452 \%$, lower than the score of indirect effect of teacher training on teacher's performance through understanding of curriculum $(5,674 \%)$. Direct effect of teacher's teaching experience on teacher's performance has a score of 3,098\%. It is low compared to indirect effect of teacher's teaching experience on teacher's performance through understanding of the curriculum $(4,189 \%)$. The same result is shown for the effect of principal's leadership on teacher's performance. The direct effect has a score of $13,469 \%$, lower than the score of indirect effect $(16,919 \%)$ of principal's leadership on teacher's performance if accompanied by understanding of the curriculum. The effect of teacher's understanding of the curriculum on teacher's performance has a score of $7,398 \%$. Meanwhile, the effect of other variables on teacher's performance has a score of $26,4 \%$. This result suggests that the variable of Understanding of the Curriculum serves as an intervening variable. So, teacher training, teaching experience, leadership of the principle will greatly affect teacher's performance if they are followed by teacher's understanding of the curriculum.

In hypothesis testing, it was known that teacher's performance could be affected by teacher training, teaching experience, principal's leadership and teacher's understanding of the curriculum. According to the result of data processing in SPSS and the result of first analysis, teacher training significantly affect teacher's performance in teaching. It is in line with the result of Nengwekhulu's (2008) and Santoso's (2012) studies which also suggest teacher's teaching experience affecting teacher's performance. As Musfah (2011: 48) stated, teaching experience is one of teacher's valuable assets to improve their teaching performance in the classroom. Ever being a teacher or long experience as a teacher will ease teacher in doing activities and jobs according to their authority.

Moreover, related to the role of principal leadership, the result of this research supports the opinion by Barnawi and Arifin (2012:74) who stated that principal's leadership plays an important role in determining teacher's perfomance. Furthermore, this research also suggests that teacher's understanding of subject curriculum will affect teaching performance. As Nasution (2012: 3) said, the quality of education depends on the quality of teacher which depends on teacher's understanding of curriculum.

\section{Conclusions}

Based on findings and discussion elaborated above, it can be concluded that teacher training, teaching experience and leadership of the principal has a positive and significant effect on Social Science teacher's understanding of the curriculum at state senior high schools in Pariaman City. this means that better teacher training, teaching experience, and leadership of the principal will result in 
better teaching performance of Social Science teachers in state senior high schools in Pariaman City. The same goes to the effect of teacher training, teaching exeperience, leadership of the principle and teacher's understanding of the curriculum on teacher's performance which has a significant positive effect. This also indicates that teacher's performance is constributed by training and upgrading, teaching experience, principal' leadership and understanding of the curriculum.

\section{Acknowledgments}

Actually, the article was a part of my thesis. Then, I would like to thank for my entire Professor (Prof. Dr. Syamsul Amar, M.S. and Prof. Dr. Azwar Ananda, M.A.) whom supporting me to do the research. All of them were inspiring me to complete my study. I also would like to thank for all of the leaders, the teacher of social science at state senior high schools in Pariaman City and academician who involved the research.

\section{References}

Akhirmen. (2012). Statistika 1: Teori dan Aplikasi. Padang: Fakultas Ekonomi Universitas Negeri Padang.

Arikunto, Suharsimi. (2007). Prosedur Penelitian: Suatu Pendekatan Praktek: Edisi Revisi. Jakarta: Rineka Cipta.

Ason, Y. (2013). Peranan Kepemimpinan Kepala Sekolah Dan rofesionalisme GuruDalam Implementasi Kurikulum Tingkat Satuan Pendidikan Di Sekolah Dasar. Jurnal Pendidikan Dasar. Vol. 1, No. 1, Tahun 2013 (Hal 58-108).

Bangun, Wilson. (2012). Manajemen Sumber Daya Manusia. Jakarta: Erlangga.

Barnawi dan Arifin Muhammad. 2012. Kinerja Guru Profesional: Instrumen Pembinaan, Peningkatan, dan Penilaian. Jogiakarta: Ar-Ruzz Media.

Bogler, Ronit. (2001). The Influenceof Leadership Style on Teacher Job Satisfaction. Sage Journals: Educational Administration Quarterly. 2001.

Danim, Sudarwan. (2011). Pengembangan Profesi Guru: Dari Pra-Jabatan, Induksi, ke Profesional Madani. Jakarta: Kencana.

Dantes, Nyoman. (2012). Metode Penelitian. Yogyakarta: Andi Offset.

Hasibuan, Malayu S.P. (2010). Manajemen Sumber Daya Manusia. Jakarta: PT Bumi Aksara.

Irianto, Agus. (2010). Statistik: Konsep Dasar, Aplikasi, dan Pengembangannya. Jakarta: Kencana Prenada Media Group.

Iskandar. (2009). Metodologi Penelitian Kualitatif. Jakarta: Gaung Persada Press.

Janice, Huber, M. Shaun Murphy, D. Jean Clandinin. (2011). Advances in Research on Teaching, Volume 14. Emerald Group Publishing Limited, pp.1 - 10

Kamil, Mustofa. (2010). Model Pendidikan dan Pelatihan: Konsep dan Aplikasi. Bandung: Alfabeta.

Kementrian Pendidikan dan Kebudayaan. (2012). Pedoman Pelaksanaan Penilaian Kinerja Guru. Jakarta.

Kunandar. (2007). Guru Profesional: Implementasi Kurikulum Tingkat Satuan Pendidikan (KTSP) dan Persiapan Menghadapi Sertifikasi Guru. Jakarta: PT Raja Grafindo Persada.

Kurniadin, Didin dan Imam Machali. (2012). Manajemen Pendidikan: Konsep dan Prinsip Pengelolaan Pendidikan. Jogjakarta: Ar-Ruzz Media.

Laeli Mafudah, Asrori. (2016). Pengaruh Pemahaman Kurikulum, Motivasi Kerja, Dan Kepemimpinan Kepala Sekolah Terhadap Kinerja Guru SMK. Economic Education Analysis Journal. Vol. 5 No.2 Tahun 2016 (Hal 389-401).

Lubis, Syahron. (2011). Metodologi Penelitian Pendidikan. Padang: Sukabina Press.

Martono, Nanang. (2010). Metode Penelitian Kuantitatif: Analisis Isi dan Analisis Data Sekunder. Jakarta: RajaGrafindo Persada.

Mondy, Wayne R. (2008). Manajemen Sumber Daya Manusia. Jakarta: Erlangga. 
Mukhtar dan Iskandar. (2009). Orientasi Baru Supervisi Pendidikan. Jakarta: Gaung Persada Pers. Mulyasa. (2011). Manajemen Pendidikan Karakter. Jakarta: Bumi Aksara.

Musfah, Jejen. (2011). Peningkatan Kompetensi Guru: Melalui Pelatihan dan Sumber Belajar Teori dan Praktik. Jakarta: Kencana Prenada Media Group.

Muslich, Mansur. (2007). Sertifikasi Guru Menuju Profesionalisme Pendidik. Jakarta: Bumi Aksara.

Nasution. (2012). Kurikulum dan Pengajaran. Jakarta: Bumi Aksara.

Nengwekhulu, R.H. (2008). Reflection on Improving Teacher Performance. Africa Educational Review. Vol 5 Tahun 2008 (Hal 338-335).

Notoatmodjo, Soekidjo. (2009). Pengembangan Sumber Daya Manusia. Jakarta: Rineka Cipta.

Putri, Oky Estiana dan Mahmud, Amir. (2016). Pengaruh Pemahaman Kurikulum, Supervisi Akademik, Dan Fasilitas Kerja Terhadap Kinerja Guru Ekonomi SMA/MA Negeri Di Kota Magelang. Economic Education Analysis Journal Vol 5 No 1 Tahun 2016

Riduwan dan Engkos Achmad Kuncoro. (2011). Cara Menggunakan dan Memaknai Analisis Jalur (Path Analisys). Jakarta. Alfabeta.

Rivai, Viethzal. (2005). Manajemen SDM.: Untuk Perusahaan Dari Teori Ke Praktek. Jakarta: Raja Grafindo Persada.

Ross, John A, and Gray Peter. (2007). TRasnformational Leadership and Theacer Commitment to Organizational Values: The Mediating Effects of Collective Teacher Efficacy. School Effectiveness and School Improvement Journal. Vol 17 Tahun 2007.

Rusman. (2011). Model-Model Pembelajaran: Mengembangkan Profesionalisme Guru. Jakarta: RajaGrafindo Persada.

Sagala, Syaiful. (2009). Kemampuan Profesional Guru dan tenaga Kependidikan. Bandung: Alfabeta.

Sagala, Syaiful. (2010). Supervisi Pembelajaran: dalam Profesi Pendidikan. Bandung: Alfabeta.

Sallis, Edward. (2010). Manajemen Mutu Terpadu Pendidikan. Yogyakarta: IRCiSoD.

Sanjaya, Wina. (2009). Kurikulum dan Pembelajaran: Teori dan Praktik Pengembangan Kurikulum Tingkat Satuan Pendidikan (KTSP). Jakarta: Kencana Prenada Media Group.

Santoso, Budi. (2012). Pengaruh Pelatihan dan Budaya Organisasi terhadap Kinerja Guru Sekolah Menengah Pertama (SMP) Negeri di DKI Jakarta. Jurnal Pendidikan Islam Tarbawi. Vol 1 Tahun 2012.

Santoso, Singgih. (2010). SPSS Statistik Parametrik. Jakarta: PT Elex Media Komputindo Gramedia.

Sardiman. (2008). Interaksi dan Motivasi Belajar Mengajar. Jakarta: RajaGrafindo Persada.

Sitepu, Nirwana. (1994). Analisis Jalur (Path Analysis). Bandung: Unit Pelayanan Jurusan Statistika, FMIPA Universitas Padjadjaran.

Stoner, James A.F dan R. Edward Freeman. (1994). Manajemen Edisi Kelima Jilid 1. Jakarta: Intermedia.

Sudjana, Nana. (2009). Dasar-Dasar Proses Belajar Mengajar. Bandung: Sinar Baru Algensindo.

Suetjipto dan Raflis Kosasi. (1999). Profesi Keguruan. Jakarta: Rineka Cipta.

Sugiyono. (2009). Metode Penelitian Administrasi. Bandung: Alfabeta

Sulistiya, Mukhamad. (2013). Pengaruh Kepemimpinan Kepala Sekolah Terhadap Kinerja Guru. Jurnal Ilmiah Pendidikan Ekonomi IKIP Veteran Semarang. Vol. 1 No. 2, Oktober 2013

Susanto, Hary. (2012). Faktor-Faktor Yang Mempengaruhi Kinerja Guru Sekolah Menengah Kejuruan. Jurnal Pendidikan Vokasi, Vol 2, Nomor 2, Juni 2012 (Hal 197-212).

Sutjipto. (2016). Pentingnya Pelatihan Kurikulum 2013 Bagi Guru. Jurnal Pendidikan dan Kebudayaan, Vol. 1, Nomor 2, Agustus 2016. (Hal 235-260).

Tschannen-Moran, Megan, dan WoolfolkHoy, Anita. (2007). The Differential Antecedents of Self-Efficacy Beliefs of Novice and Experienced Teachers. Teaching and Teacher Education Journal. Vol 23 Tahun 2007 (Hal 944-956).

Undang-Undang Guru dan Dosen: UU. RI No.14. Tahun 2005.

Uno, Hamzah. (2010). Profesi Kependidikan. Jakarta. Bumi Aksara.

Wahyudi. (2009). Kepemimpinan Kepala Sekolah: Dalam Organisasi Pembelajar (Learning Organization). Bandung: Alfabeta. 
Widanaputra, A.A.G.P. (2007). Pengaruh Konflik Antara Pemegang Saham Dan Manajemen Mengenai Kebijakan Deviden Terhadap Konservatisma Akuntansi. Disertasi Program Doktor Akuntansi Fakultas Ekonomi Universitas Gajah Mada Yogyakarta.

Wiyana, Sri Anitah dan Samsi Haryanto. (2013). Pengaruh Pengetahuan KTSP Dan Pendidikan Terhadap Kemampuan Menyusun RPP Guru SDN Jatiyoso Tahun 2011/ 2012. Jurnal Teknologi Pendidikan, Vol 1, No2, 2013 (hal 239-248) (http://jurnal.pasca.uns.ac.id., diakses pada 4 April 2014).

Yamin, Martinis. (2007). Personalisasi Guru dan Implementasi KTSP. Jakarta: Gaung Persada Press. Yamin dan Maisah. (2010). Standarisasi Kinerja Guru. Jakarta: Gaung Persada Press.

Zuhriyah, Siti. (2014). Pengaruh Pengalaman Mengajar Guru Dan Kepemimpinan Kepala Sekolah Terhadap Kinerja Guru Sd Kecamatan Kasihan Kabupaten Bantul. Jurnal Elementari School 1. Volume 1, No 2 Tahun 2014. 